\title{
BDNF Mediates Neuroprotection against Oxygen-Glucose Deprivation by the Cardiac Glycoside Oleandrin
}

\author{
Michael J. Van Kanegan, ${ }^{1,2 \star}$ Dong Ning He, ${ }^{1,2 \star}$ Denise E. Dunn, ${ }^{1,2 \star}$ Peiying Yang, ${ }^{3}$ Robert A. Newman, ${ }^{3}$ Anne E. West, ${ }^{2}$ \\ and Donald C. Lo ${ }^{1,2}$ \\ ${ }^{1}$ Center for Drug Discovery and ${ }^{2}$ Department of Neurobiology, Duke University Medical Center, Durham, North Carolina 27704, and ${ }^{3}$ Department of \\ Experimental Therapeutics, The University of Texas, M. D. Anderson Cancer Center, Houston, Texas 77030
}

We have previously shown that the botanical drug candidate PBI-05204, a supercritical $\mathrm{CO}_{2}$ extract of Nerium oleander, provides neuroprotection in both in vitro and in vivo brain slice-based models for focal ischemia (Dunn et al., 2011). Intriguingly, plasma levels of the neurotrophin BDNF were increased in patients treated with PBI-05204 in a phase I clinical trial (Bidyasar et al., 2009). We thus tested the hypothesis that neuroprotection provided by $\mathrm{PBI}-05204$ to rat brain slices damaged by oxygen-glucose deprivation (OGD) is mediated by BDNF. We found, in fact, that exogenous BDNF protein itself is sufficient to protect brain slices against OGD, whereas downstream activation of TrkB receptors for BDNF is necessary for neuroprotection provided by PBI-05204, using three independent methods. Finally, we provide evidence that oleandrin, the principal cardiac glycoside component of PBI-05204, can quantitatively account for regulation of BDNF at both the protein and transcriptional levels. Together, these findings support further investigation of cardiac glycosides in providing neuroprotection in the context of ischemic stroke.

\section{Introduction}

Stroke is the fourth-leading cause of death in the U.S., with almost 800,000 new cases occurring each year and further increases expected with the aging population (National Stroke Association, 2010). Although major advances have been made in reducing stroke risk, treatments are still lacking that provide direct neuroprotection and/or neuroresuscitation, despite $>50$ drug candidates having been tested to date in late-stage clinical trials (Suwanwela and Koroshetz, 2007; Zaleska et al., 2009). Thus, the only FDA-approved drug for stroke remains the intravenous "clot buster" recombinant tissue plasminogen activator (Albers et al., 2011).

We have previously reported that the botanical drug candidate PBI-05204, a defined supercritical $\mathrm{CO}_{2}$ extract of Nerium oleander, provides significant neuroprotection to neural tissues damaged by oxygen-glucose deprivation (OGD), as occurs in ischemic stroke (Dunn et al., 2011). Critically, we demonstrated that PBI-05204 can still provide significant neuroprotection even when administrated with a $4-6$ h delay following OGD, and that the neuroprotective activity of PBI-05204 is blood-brain barrier (BBB)-penetrant. Finally, we showed that this neuroprotection is

\footnotetext{
Received June 25, 2013; revised Nov. 25, 2013; accepted Nov. 28, 2013.

Author contributions: M.J.V.K., D.N.H., D.E.D.,P.Y., R.A.N., A.E.W., and D.C.L. designed research; M.J.V.K., D.N.H., and D.E.D. performed research; P.Y., R.A.N., A.E.W., and D.C.L. contributed unpublished reagents/analytic tools; M.J.V.K., D.N.H., D.E.D., and D.C.L. analyzed data; M.J.V.K., D.N.H., and D.C.L. wrote the paper.

This work was supported in part by NIH Grant NS074379 and by funding provided by Phoenix Biotechnology. Conflict of Interest: P. Yang and R. Newman are paid consultants of Phoenix Biotechnology.

${ }^{*}$ M.J.V.K., D.N.H., and D.E.D. contributed equally to this work.

Correspondence should be addressed to Dr Donald C. Lo, Center for Drug Discovery and Department of Neurobiology, Duke University Medical Center, 4321 Medical Park Drive, Suite 200, Durham, NC 27704. E-mail: lo@neuro.duke.edu.

DOI:10.1523/JNEUROSCI.2700-13.2014

Copyright $\odot 2014$ the authors $\quad 0270-6474 / 14 / 340963-06 \$ 15.00 / 0$
}

mediated, at least in major part, by the cardiac glycoside molecule oleandrin. In fact, this principal bioactive and BBB-penetrant constituent of PBI-05204 was the original impetus for the study, as oleandrin is closely related in structure to neriifolin, which we had previously identified as the strongest hit from a highthroughput and hypothesis-neutral chemical biology screen for neuroprotective agents using a brain slice-based model of focal ischemia (Wang et al., 2006). However, the mechanism(s) by which cardiac glycosides provide neuroprotection has remained unknown.

We report here that the neuroprotection provided by PBI05204 appears to be mediated through augmentation of endogenous levels of the neurotrophin brain-derived neurotrophic factor (BDNF). We show that inhibition of BDNF signaling via its cognate receptor, TrkB, blocks the neuroprotection provided by PBI-05204, and that in turn recombinant BDNF itself is able to provide significant neuroprotection to OGD-treated brain slices. Finally, we provide evidence that augmentation of BDNF levels by PBI-05204 can be qualitatively and quantitatively accounted for by its principal cardiac glycoside component, oleandrin, at both the protein and gene transcriptional levels. Together with positive safety data already established in a phase I clinical trial (Bidyasar et al., 2009), these results support continued investigation of PBI-05204 as a drug lead candidate providing neuroprotection in stroke and potentially other traumatic and/or neurodegenerative conditions of the CNS.

\section{Materials and Methods}

Compounds. PBI-05204 was provided by Phoenix Biotechnology and is an ethanol-modified supercritical $\mathrm{CO}_{2}$ extract of Nerium oleander (Newman et al., 2008). Pure oleandrin was purchased from ChromaDex. Stock solutions were made in DMSO and diluted into brain slice culture medium to a final DMSO concentration of $0.1 \%$ for all conditions. The 
BDNF-neutralizing monoclonal antibody mAb\#9 was provided by the Developmental Studies Hybridoma Bank at the University of Iowa; a matching preimmune IgG2 isotype control was purchased from BioLegend.

Brain slice preparation and transfection. Coronal brain slices ( $250 \mu \mathrm{m}$ thick) from postnatal day 10 Sprague-Dawley rat pups of either sex (Charles River) were prepared and placed in acute organotypic culture as previously described (Braithwaite et al., 2010; Dunn et al., 2011). Animals were killed in accordance with NIH guidelines and under Duke IACUC approval and oversight. Brain tissues were sliced in ice-cold artificial CSF (ACSF), and subjected to OGD by suspension in glucose-free, $\mathrm{N}_{2}$ bubbled ACSF containing low $\mathrm{O}_{2}(<0.5 \%)$ for $5.5 \mathrm{~min}$, after which control and OGD-treated brain slices were plated in interface configuration on top of culture medium (Neurobasal A medium supplemented with $15 \%$ heatinactivated horse serum, $10 \mathrm{~mm} \mathrm{KCl}, 10 \mathrm{~mm}$ HEPES, $100 \mathrm{U} / \mathrm{ml}$ penicillin/streptomycin, 1 mu sodium pyruvate, and $1 \mathrm{~mm}$ L-glutamine) set in $0.5 \%$ reagent-grade agarose. One hour after cutting, brain slices were biolistically transfected with DNAs encoding yellow fluorescent protein (YFP) and/or TrkB.T1 receptor as previously described (Yacoubian and Lo, 2000). Brain slice explants were incubated for $24 \mathrm{~h}$ under $5 \% \mathrm{CO}_{2}$ at $37^{\circ} \mathrm{C}$. PBI- 05204 or oleandrin was added to culture medium at the time of brain slice explantation.

Assessment of neuroprotection. Twenty-four hours after their preparation, brain slice explants were assessed for neuroprotection by scoring numbers of healthy pyramidal neurons in the cortical regions of each brain slice as previously described (Wang et al., 2006; Dunn et al., 2011). Briefly, pyramidal neurons were identified by their positions and orientations within the cortex and were scored as healthy if exhibiting: (1) a clear and continuously labeled cell body with no obvious signs of shrinkage or collapse, (2) a fully and continuously labeled apical dendrite of normal length, and (3) $>2$ clear basal dendrites $>2$ cell body diameters long. All experimental runs were done using single litters of animals (males and females), with brain slices from the littermates pooled and $N=12-18$ brain slices randomly assigned to each experimental condition. Data from at least three independent experimental runs are presented as mean numbers of healthy cortical neurons per brain slice, or as a percentage increase over those surviving in the OGD condition \pm SD.

Statistical analysis. For all neuroprotection assays, statistical significance was tested using ANOVA followed by Dunnett's post hoc comparison test at the 0.01 confidence level.

Western blotting. Lysates from brain slice explants were prepared as previously described (Dunn et al., 2011). Total TrkB or EGF receptor protein levels were assessed by immunoblotting whole brain slice lysates using a pan-Trk antibody (C-14, 1:3000; Santa Cruz Biotechnology) or EGF receptor antibody (C74B9, 1:1000; Cell Signaling Technology), respectively. Phospho-TrkB or phospho-EGF receptor levels were quantified by immunoprecipitation against phosphotyrosine (4G10, $3.5 \mu \mathrm{g} / \mathrm{ml}$; Millipore) with protein-G agarose, followed by immunoblotting with C-14 or C74B9, respectively. Equivalent total protein amounts were loaded in each lane as determined by BCA protein assay (Pierce).

ELISA. Brain slices were washed three times with PBS, flash frozen in liquid $\mathrm{N}_{2}$ and stored at $-80^{\circ} \mathrm{C}$ until use. Samples were thawed on ice and homogenized in cold lysis buffer containing $100 \mathrm{~mm}$ Tris/ $\mathrm{HCl} \mathrm{pH} \mathrm{7,} \mathrm{2 \%}$ BSA, $1 \mathrm{~m} \mathrm{NaCl}, 4 \mathrm{~mm}$ EDTA, $2 \%$ Triton X-100, and $0.1 \%$ sodium azide supplemented with Complete Mini protease inhibitor cocktail tablets (Roche) and $17 \mu \mathrm{g} / \mathrm{ml}$ PMSF. Following centrifugation at $14,000 \times g$ for

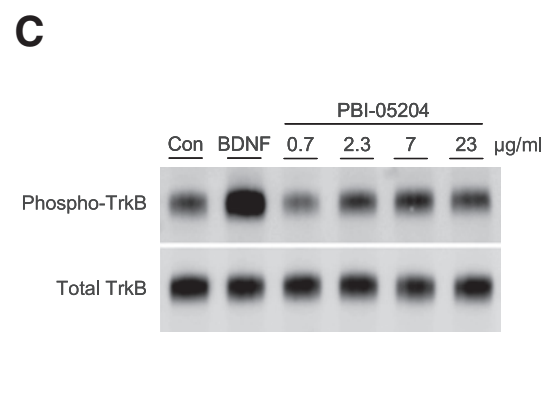

D

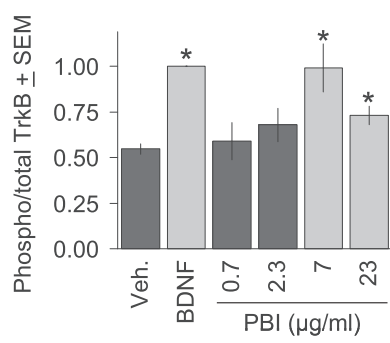

oleandrin $(\mu \mathrm{M})$ 
A
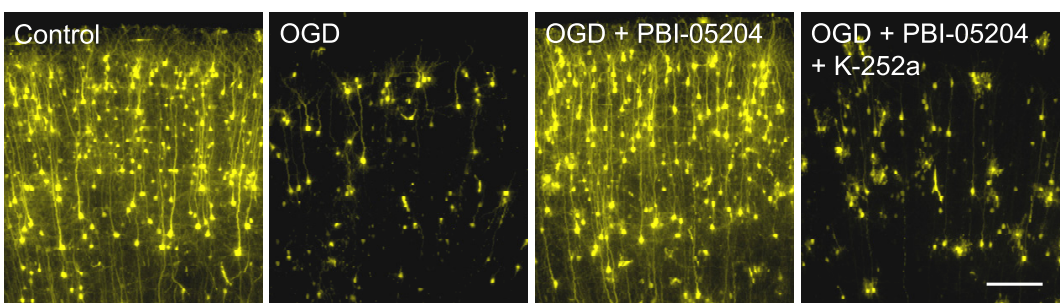

B

C
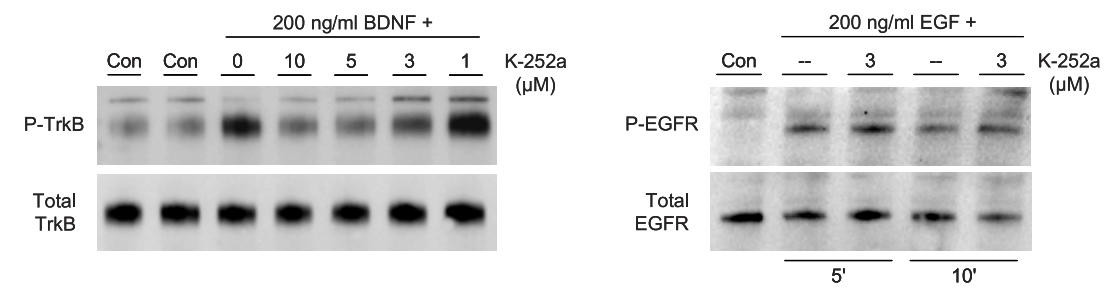

D

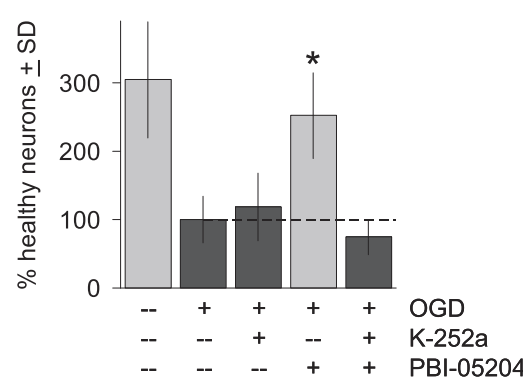

$\mathbf{E}$

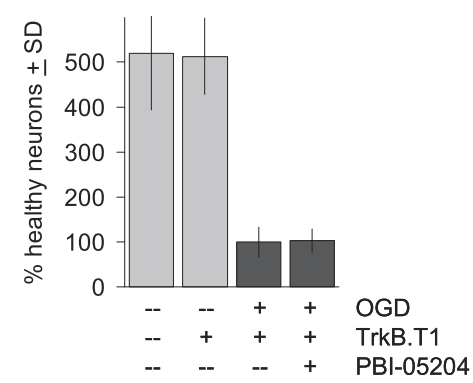

$\mathbf{F}$
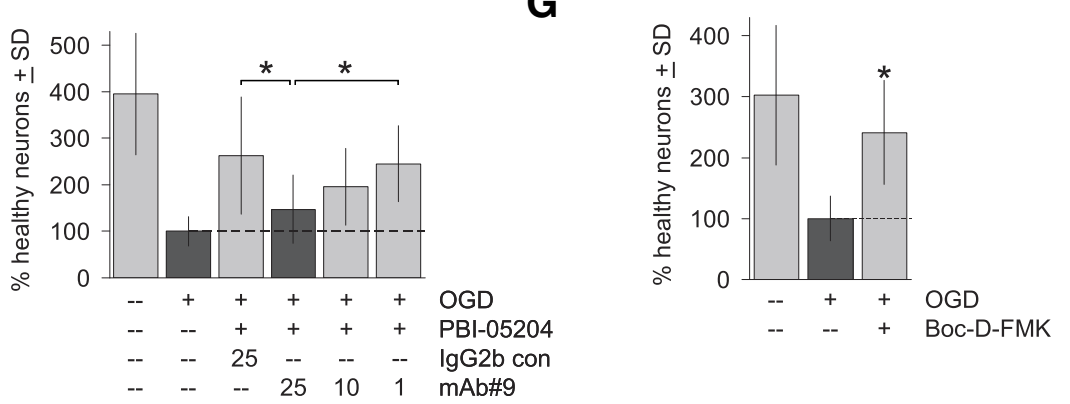

Figure 2. TrkB receptor activation is required for the neuroprotective effects of PBI-05204.A, Representative photomicrographs showing that neurodegeneration induced by transient $0 \mathrm{GD}$ can be quantitatively rescued by $23 \mu \mathrm{g} / \mathrm{ml} \mathrm{PBI-05204}$ (compare first three panels). Neuroprotection by PBI-05204 is completely blocked by a minimal concentration of K-252a ( $3 \mu \mathrm{M})$ that inhibits the majority of TrkB autophosphorylation ("P-TrkB") induced by $1 \mathrm{~h}$ of treatment with $200 \mathrm{ng} / \mathrm{ml} \mathrm{BDNF}$ as shown in the representative immunoblot in B. Scale bar, $200 \mu \mathrm{m}$. C, In contrast, $3 \mu \mathrm{m}$ K-252a had no effect on the activation and autophosphorylation of EGFR by 5 or $10 \mathrm{~min}$. of treatment with $200 \mathrm{ng} / \mathrm{ml}$ EGF under the identical experimental conditions. D, Quantification of brain slice assays showing that $3 \mu \mathrm{m} \mathrm{K}-252 \mathrm{a}$ completely blocks the neuroprotection provided by $23 \mu \mathrm{g} / \mathrm{ml} \mathrm{PBI-05204}$ (compare fourth and fifth bars) but has no significant effect on general neuronal health even in OGD-treated brain slices (compare second and third bars). $y$-Axis shows the percentage increase in numbers of healthy cortical neurons per brain slice relative to the OGD condition. $\boldsymbol{E}_{\text {, }}$ Cotransfection with dominant-negative, truncated TrkB.T1 also blocks neuroprotection by $23 \mu \mathrm{g} / \mathrm{ml} \mathrm{PBI-05204}$. Although TrkB.T1 has no effect on control brain slices (light bars), it completely blocks the neuroprotective effects of PBI-05204 (dark bars). $\boldsymbol{F}$, Finally, the BDNF-neutralizing antibody mAb\#9 (Kolbeck et al., 1999) was used as a third independent method to show that disrupting BDNF-TrkB signaling inhibits the neuroprotective activity of $23 \mu \mathrm{g} / \mathrm{ml} \mathrm{PBI-05204.} \mathrm{mAb \# 9} \mathrm{was} \mathrm{applied} \mathrm{to} \mathrm{brain} \mathrm{slice} \mathrm{explants} \mathrm{at} \mathrm{the}$ concentrations shown (in $\mu \mathrm{g} / \mathrm{ml})$. Significant blockade of the neuroprotective effects of PBI-05204 compared with the preimmune IgG2 isotype control was observed in the concentration range previously reported for mAb\#9 (Deogracias et al., 2012). G, Neuronal degeneration induced by transient 0 GD was rescuable by the pan-caspase inhibitor BoC-D-FMK (100 $\mu \mathrm{M})$. D-G, Averages of three independent runs are shown; ${ }^{*} p<0.01$ by ANOVA followed by Dunnett's post hoc comparison test.

side oleandrin, the principal known bioactive component of PBI05204 (Newman et al., 2008), also increased BDNF expression in brain slices in a parallel concentration range given its $\sim 3 \%$ relative abundance in PBI-05204 (Dunn et al., 2011).
We further showed that increases in BDNF expression induced by PBI-05204 resulted in increased activation of endogenous TrkB receptors as monitored by autophosphorylation (Ip et al., 1993; Fig. 1C). Apparent increases in TrkB phosphorylation were relatively modest, even for the positive control treated for $1 \mathrm{~h}$ with 200 $\mathrm{ng} / \mathrm{ml}$ recombinant $\mathrm{BDNF}$, due to high levels of basal TrkB autophosphorylation in brain slice explants reflecting active ambient BDNF signaling as we have previously shown (McAllister et al., 1997). Nevertheless, significantly increased levels of TrkB phosphorylation could be induced by PBI05204 treatment in the same concentration range as was observed in Figure $1 A$ for increasing BDNF levels (Fig. 1D).

\section{TrkB receptor activation is required for neuroprotection by PBI-05204}

That PBI-05204 treatment increases BDNF protein levels in brain slices as well as downstream activation of their cognate TrkB receptors led to the hypothesis that neuroprotection provided by PBI-05204 to brain slices damaged by OGD is mediated by BDNF. To test this hypothesis, we asked whether downstream activation of TrkB receptors by BDNF is required for neuroprotection by PBI-05204. First, we took a pharmacological approach using an inhibitor of high-affinity neurotrophin Trk receptors, the kinase inhibitor K-252a (Berg et al., 1992; Tapley et al., 1992 ). Figure $2 B$ shows that $3 \mu \mathrm{M}$ is a minimal concentration of K-252a that inhibits the majority of Trk receptor activation by BDNF (20 min pretreatment with K-252a at the indicated concentrations followed by $1 \mathrm{~h}$ of incubation with $200 \mathrm{ng} / \mathrm{ml} \mathrm{BDNF}$ as in Fig. $1 C$; note that concentrations of pharmacological agents generally have to be increased in brain slice culture media to promote tissue penetration compared with conventional dissociated cultures). $\mathrm{K}-252 \mathrm{a}$ at $3 \mu \mathrm{M}$ under identical treatment conditions did not affect signaling through a parallel receptor tyrosine kinase pathway (EGF receptor after 5 or 10 min of treatment with EGF reflecting the faster kinetics of this pathway; Fig. 2C), suggesting that the selectivity of $\mathrm{K}-252 \mathrm{a}$ for TrkB receptors is retained at this concentration. We found that this concentration of K-252a completely inhibited the neuroprotective effects of PBI05204 in OGD-treated brain slices (Fig. $2 A, D)$, but had no deleterious effects on either control brain slices transfected with YFP but not subjected to OGD $(100 \pm 18 \%$ vs $86 \pm 22 \%$ healthy neurons for control vs K-252a-treated; mean $\pm \mathrm{SD}$, difference not significant) or those that had been subjected to OGD (Fig. 2D, compare second and third bars). 
A

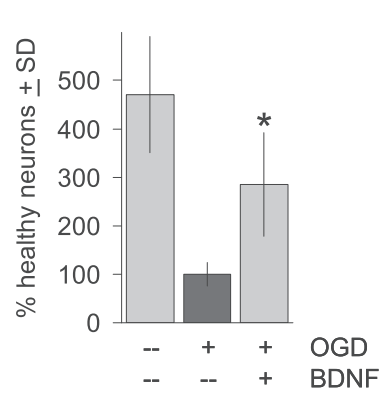

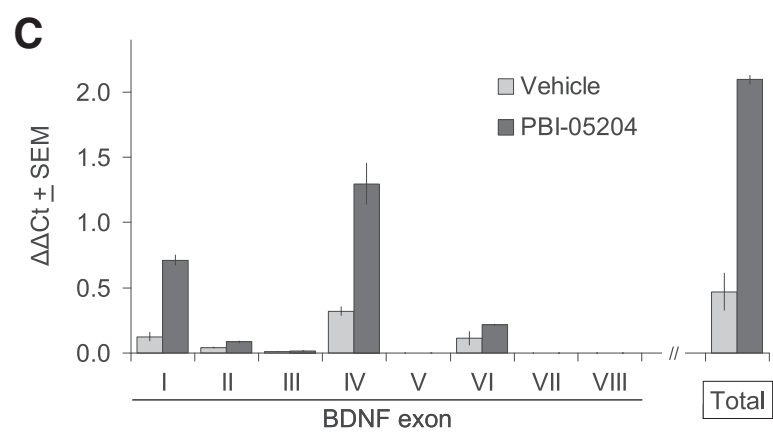

D

B
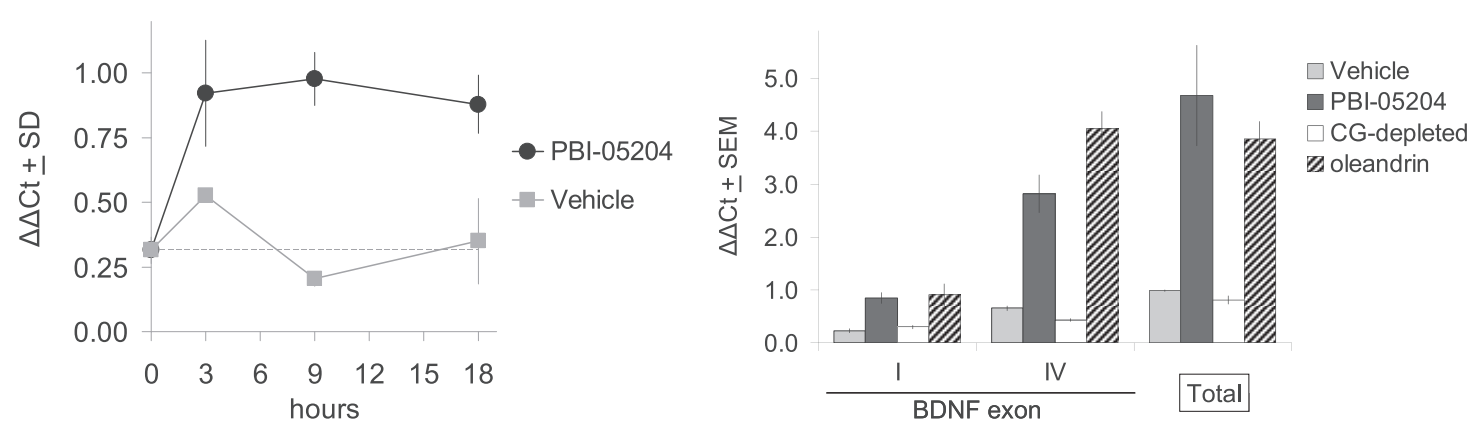

Figure 3. A, Exogenous BDNF is sufficient for neuroprotection against OGD. Addition of $200 \mathrm{ng} / \mathrm{ml}$ BDNF provides direct neuroprotection to $0 G \mathrm{GD}$-treated brain slices. $y$-Axis shows the percentage increase in numbers of healthy cortical neurons per brain slice relative to the $0 \mathrm{GD}$ condition. Average of three independent runs; ${ }^{*} p<0.01$ by ANOVA followed by Dunnett's posthoc comparison test. $\boldsymbol{B}-\boldsymbol{D}$, PBI-05204 and oleandrin regulate BDNF at the gene transcriptional level. $\boldsymbol{B}$, Time course of induction of Bdnf gene transcription by $23 \mu \mathrm{g} / \mathrm{ml} \mathrm{PBI}-05204$ as quantified by qPCR analysis of total $B d n f$ mRNA levels. $\Delta \Delta \mathrm{Ct}$, threshold cycle. $C$, Use of qPCR with specific primers to distinguish among eight alternative promoters for $B d n f$ shows that transcription is most strongly induced by PBI-05204 at promoters I and IV, with little or no induction at promoters II, III, and V-VIII. Last pair of bars shows that increases in promoters I and IV can quantitatively account for total Bdnf mRNA induction as measured by a primer set that recognizes all Bdnf transcripts. Measurements taken $9 \mathrm{~h}$ after treatment with $23 \mu \mathrm{g} / \mathrm{ml} \mathrm{PBI-05204.} \mathrm{D,} \mathrm{Three} \mathrm{micrometers} \mathrm{of} \mathrm{oleandrin} \mathrm{induces} \mathrm{Bdnf}$

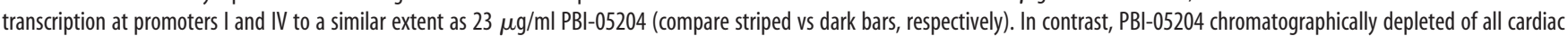
glycosides ("CG-depleted") had no effect on Bdnf gene transcription. Measurements taken $9 \mathrm{~h}$ after compound treatments.

Next, we used a second method to confirm that TrkB activation is necessary for the neuroprotection provided by PBI-05204. In these experiments, we cotransfected along with YFP a naturally occurring truncated isoform of TrkB, termed TrkB.T1, that is lacking the kinase domain and thereby acts as a dominant negative when recruited to dimerize with full-length $\operatorname{TrkB}$ receptors by BDNF ligand (Biffo et al., 1995; Eide et al., 1996). Taking advantage of the near $100 \%$ cotransfection linkage rate of biolistics (Braithwaite et al., 2010), we had previously shown that transfection of TrkB.T1 into brain slice explants profoundly alters neuronal responsiveness to BDNF (Yacoubian and Lo, 2000). Here, we show in Figure 2E that transfection of TrkB.T1 completely inhibited the neuroprotective effects of PBI-05204 in OGD-treated brain slices, confirming the results described above using a pharmacological Trk receptor antagonist.

Finally, we used a third independent method to show that $\mathrm{BDNF}-\mathrm{TrkB}$ signaling is required for the neuroprotective activity of PBI-05204, namely, a highly selective function-blocking antibody against BDNF itself, mAb\#9 (Kolbeck et al., 1999; Deogracias et al., 2012). As can be seen in Figure $2 F, \mathrm{mAb} \# 9$ inhibited the ability of PBI-05204 to protect against OGD treatment in a concentration-dependent manner, whereas a preimmune IgG2 isotype control had no significant effect.

These experiments demonstrated with three independent methods that BDNF-TrkB signaling is necessary for the neuroprotective actions of PBI-05204 in OGD-treated brain slices.

\section{BDNF is sufficient to rescue brain slices from OGD}

Conversely, we showed that exogenous BDNF alone is sufficient to rescue brain slices subjected to OGD. Treatment with 200 $\mathrm{ng} / \mathrm{ml}$ of recombinant BDNF, a concentration previously shown to retain Trk receptor selectivity and induce TrkB-specific effects in brain slice explants (Ip et al., 1993; McAllister et al., 1997; Yacoubian and Lo, 2000), resulted in significant rescue of neurons that otherwise would have degenerated over this period (Fig. $3 A$ ). Protection against such OGD treatment can also be provided by cotransfection with the anti-apoptotic gene $B c l-x L$ (Wang et al., 2006) or by application of the pan-caspase inhibitor Boc-DFMK (Fig. 2G), suggesting that a significant portion of the neuronal cell death protected against by BDNF and PBI-05204 in OGD-treated brain slices likely involves apoptotic mechanisms.

\section{PBI-05204 and oleandrin increase Bdnf transcription through selective promoters}

Given that the $B d n f$ gene is known to be highly regulatable by extracellular signals (Lyons and West, 2011), we asked whether PBI-05204-induced increases in BDNF protein levels are driven at the gene transcriptional level. In fact, as shown in Figure $3 B$, PBI-05204 treatment led to a rapid increase in the transcriptional rate of the $B d n f$ gene as assessed by quantitative PCR (qPCR), reaching a steady-state of some $4-5$ times over control levels by 3-9 h after treatment, and maintaining this level through 9-18 h.

The transcription of the $B d n f$ gene can be driven by at least eight distinct promoter/enhancer sequences that, through alternative splicing, all drive a common ninth exon encoding the entire BDNF protein sequence (Liu et al., 2006; Aid et al., 2007; Pruunsild et al., 2007; Lyons and West, 2011). qPCR analysis of these alternative transcripts indicated that promoters I and IV are the most highly induced by PBI-05204 treatment and could quantitatively account for the total increase in $B d n f$ transcription 
(Fig. 3C). PBI-05204 increased transcription at promoter VI only minimally, whereas promoters II, III, V, VII, and VIII all showed low basal levels of expression with little or no induction by PBI-05204.

Finally, we asked whether the action of oleandrin could account for the regulation of $B d n f$ by PBI-05204 at the transcriptional level. As can be seen in Figure $3 D$, treatment with an equivalent concentration of oleandrin corresponding to its $\sim 3 \%$ relative abundance in PBI-05204 drove increases in Bdnf gene expression to equivalent degrees through promoters I and IV compared with the full PBI-05204 extract. In contrast, PBI-05204 depleted of cardiac glycoside content had no effect on Bdnf transcription, at promoters I and IV or overall.

\section{Discussion}

We have demonstrated that augmentation of endogenous BDNF is both necessary and sufficient for the neuroprotective action of PBI-05204 in a brain slice model for focal ischemia, and provided evidence that oleandrin, the principal cardiac glycoside component of PBI-05204, can quantitatively account for regulation of $\mathrm{BDNF}$ at both the protein and transcriptional levels. The strongest regulation of $B d n f$ by PBI-05204 and oleandrin was via promoter IV, and to a lesser extent promoter I, strongly suggesting convergence with known pathways that regulate $B d n f$ transcription downstream of neuronal activity (Lyons and West, 2011). Regulation of promoter IV has been shown to be $\mathrm{Ca}^{2+}$-dependent and mediated via the transcription factors CaRF, USF1/2, and CREB; and MeCP2 involved in DNA methylation (for review, see Lyons and West, 2011).

This transcriptional profile for $B d n f$ regulation could plausibly be triggered by the primary target of cardiac glycosides, $\mathrm{Na}^{+}$, $\mathrm{K}^{+}$-ATPase. In heart, the inhibition of the $\mathrm{Na}^{+}, \mathrm{K}^{+}$-ATPase by digitalis compounds leads to secondary inhibition of the $\mathrm{Na}^{+}$/ $\mathrm{Ca}^{2+}$ exchanger via erosion of the transmembrane $\mathrm{Na}^{+}$gradient and consequent increases in intracellular $\mathrm{Ca}^{2+}$ levels (Hardman et al., 1996). In fact, we have previously reported that that OGD treatment of brain slices results in selective upregulation of the $\alpha 3$-subunit of the $\mathrm{Na}^{+}, \mathrm{K}^{+}$-ATPase, to which oleandrin exhibits preferential binding (Yang et al., 2009; Dunn et al., 2011).

However, the contribution of other potential neuroprotective mechanisms initiated through the $\mathrm{Na}^{+}, \mathrm{K}^{+}$-ATPase cannot be excluded, including maintaining intracellular $\mathrm{Ca}^{2+}$ "set point" implicated in neuronal survival (Lee et al., 1999, 2000); and energy conservation through ATP-sparing given that $40-70 \%$ of brain energy metabolism is allocated to powering the $\mathrm{Na}^{+}, \mathrm{K}^{+}$ATPase (Hochachka, 1986; Clausen et al., 1991; Friberg and Wieloch, 2002). Finally, there is accumulating evidence that the $\mathrm{Na}^{+}$, $\mathrm{K}^{+}$-ATPase functions within a stable signalosome, and mediates signal transduction through multiple pathways including EGFR and downstream MAPK pathways (for review, see Xie and Cai, 2003; Prassas and Diamandis, 2008).

Although the neuroprotective properties of oleandrin and PBI-05204 may seem surprising, digitalis compounds such as digoxin have been in continuous clinical usage since the 18th century (Withering, 1785). We first identified the neuroprotective potential of such cardiac glycoside compounds in a largescale, hypothesis-neutral chemical biology screen in a brain slice OGD assay (Wang et al., 2006). The strongest hit from this screen was the cardiac glycoside neriifolin which we subsequently showed could also provide benefit in two whole-animal models for stroke, including the adult middle cerebral occlusion model (Wang et al., 2006). However, penetration of the FDA-approved cardiac glycoside, digoxin, into CNS is limited by the efflux trans- porter P-glycoprotein expressed in the $\mathrm{BBB}$ (Beringer and Slaughter, 2005), and BBB penetration of neriifolin is also modest (Zhao et al., 1986). In contrast, oleandrin is readily BBBpenetrant in rodent models, as we have previously reported (Dunn et al., 2011).

Thus, our findings here that the neuroprotective actions of PBI-05204 in brain slice assays is mediated at least in part by BDNF further supports potential therapeutic applications of cardiac glycosides in ischemic stroke. BDNF is a principal neurotrophic factor during brain development as well as in the adult, and has been associated with neuroprotective benefit in a broad range of CNS traumatic and neurodegenerative disorders, including stroke (Zaleska et al., 2009; Nagahara and Tuszynski, 2011; Hartmann et al., 2012). In fact, endogenous BDNF has been implicated in neuronal survival following ischemia (Larsson et al., 1999; Ke et al., 2011), and treatment with exogenous BDNF postischemia has been shown to be neuroprotective and contribute to recovery and neural regeneration (Schäbitz et al., 2007; for review, see Zaleska et al., 2009; Rothman and Mattson, 2013).

However, the BDNF protein itself has proven problematic as a clinical agent, due to short serum half-life, poor bioavailability, minimal BBB-penetrability, and limited diffusion within CNS tissues (Thoenen and Sendtner, 2002; Longo and Massa, 2013; Lu et al., 2013). There has thus been strong interest in developing small molecule mimetics of BDNF or drug therapies that increase endogenous expression of BDNF (for review, see Obianyo and Ye, 2013; Rothman and Mattson, 2013). In contrast, cardiac glycoside drugs have been in effective clinical usage for decades (Hardman et al., 1996) and we have previously shown that oleandrin displays excellent brain penetration (Dunn et al., 2011). In addition, it is notable that PBI-05204 was well tolerated in a phase I clinical trial for a non-CNS indication (Bidyasar et al., 2009).

Interestingly, the recently FDA-approved drug fingolimod for multiple sclerosis has been shown to regulate BDNF production (Deogracias et al., 2012). In fact, fingolimod has been shown also to be effective in a range of preclinical stroke models (Campos et al., 2013) and may transpire to exert its neuroprotective effects at least in part through a BDNF mechanism. Given the wide range of neurological and neuropsychiatric disorders in which BDNF has been implicated (Longo and Massa, 2013; Lu et al., 2013), small molecule compounds such as fingolimod and oleandrin/PBI-05204 reported here may merit further investigation in ischemic stroke as well as other disorders of the CNS.

\section{References}

Aid T, Kazantseva A, Piirsoo M, Palm K, Timmusk T (2007) Mouse and rat BDNF gene structure and expression revisited. J Neurosci Res 85:525535. CrossRef Medline

Albers GW, Goldstein LB, Hess DC, Wechsler LR, Furie KL, Gorelick PB, Hurn P, Liebeskind DS, Nogueira RG, Saver JL (2011) Stroke treatment academic industry roundtable (STAIR) recommendations for maximizing the use of intravenous thrombolytics and expanding treatment options with intra-arterial and neuroprotective therapies. Stroke 42 : 2645-2650. CrossRef Medline

Berg MM, Sternberg DW, Parada LF, Chao MV (1992) K-252a inhibits nerve growth factor-induced trk proto-oncogene tyrosine phosphorylation and kinase activity. J Biol Chem 267:13-16. Medline

Beringer PM, Slaughter RL (2005) Transporters and their impact on drug disposition. Ann Pharmacother 39:1097-1108. CrossRef Medline

Bidyasar S, Kurzrock R, Falchook GS, Naing A, Wheler JJ, Durand J, Yang P, Johansen MJ, Newman RA, Khan R, Hong D (2009) A first-in-human phase I trial of PBI-05204 (oleandrin), an inhibitor of Akt, FGF-2, NF-kB, and p70S6K in advanced solid tumor patients. J Clin Oncol 27:3537.

Biffo S, Offenhäuser N, Carter BD, Barde YA (1995) Selective binding and 
internalisation by truncated receptors restrict the availability of BDNF during development. Development 121:2461-2470. Medline

Braithwaite SP, Schmid RS, He DN, Sung ML, Cho S, Resnick L, Monaghan MM, Hirst WD, Essrich C, Reinhart PH, Lo DC (2010) Inhibition of c-Jun kinase provides neuroprotection in a model of Alzheimer's disease. Neurobiol Dis 39:311-317. CrossRef Medline

Campos F, Qin T, Castillo J, Seo JH, Arai K, Lo EH, Waeber C (2013) Fingolimod reduces hemorrhagic transformation associated with delayed tissue plasminogen activator treatment in a mouse thromboembolic model. Stroke 44:505-511. CrossRef Medline

Clausen T, Van Hardeveld C, Everts ME (1991) Significance of cation transport in control of energy metabolism and thermogenesis. Physiol Rev 71:733-774. Medline

Deogracias R, Yazdani M, Dekkers MP, Guy J, Ionescu MC, Vogt KE, Barde YA (2012) Fingolimod, a sphingosine-1 phosphate receptor modulator, increases BDNF levels and improves symptoms of a mouse model of Rett syndrome. Proc Natl Acad Sci U S A 109:14230-14235. CrossRef Medline

Dunn DE, He DN, Yang P, Johansen M, Newman RA, Lo DC (2011) In vitro and in vivo neuroprotective activity of the cardiac glycoside oleandrin from Nerium oleander in brain slice-based stroke models. J Neurochem 119:805-814. CrossRef Medline

Eide FF, Vining ER, Eide BL, Zang K, Wang XY, Reichardt LF (1996) Naturally occurring truncated trkB receptors have dominant inhibitory effects on brain-derived neurotrophic factor signaling. J Neurosci 16:3123-3129. Medline

Friberg H, Wieloch T (2002) Mitochondrial permeability transition in acute neurodegeneration. Biochimie 84:241-250. CrossRef Medline

Hardman JG, Limbird LE, Milinoff PB, Ruddon RW, Gilman AG (1996) Goodman and Gilman's: the pharmacological basis of therapeutics. New York: McGraw-Hill.

Hartmann D, Drummond J, Handberg E, Ewell S, Pozzo-Miller L (2012) Multiple approaches to investigate the transport and activity-dependent release of BDNF and their application in neurogenetic disorders. Neural Plast 2012:203734. CrossRef Medline

Hochachka PW (1986) Defense strategies against hypoxia and hypothermia. Science 231:234-241. CrossRef Medline

Ip NY, Stitt TN, Tapley P, Klein R, Glass DJ, Fandl J, Greene LA, Barbacid M, Yancopoulos GD (1993) Similarities and differences in the way neurotrophins interact with the Trk receptors in neuronal and nonneuronal cells. Neuron 10:137-149. CrossRef Medline

Ke Z, Yip SP, Li L, Zheng XX, Tong KY (2011) The effects of voluntary, involuntary, and forced exercises on brain-derived neurotrophic factor and motor function recovery: a rat brain ischemia model. PLoS ONE 6:e16643. CrossRef Medline

Kolbeck R, Bartke I, Eberle W, Barde YA (1999) Brain-derived neurotrophic factor levels in the nervous system of wild-type and neurotrophin gene mutant mice. J Neurochem 72:1930-1938. Medline

Larsson E, Nanobashvili A, Kokaia Z, Lindvall O (1999) Evidence for neuroprotective effects of endogenous brain-derived neurotrophic factor after global forebrain ischemia in rats. J Cereb Blood Flow Metab 19: 1220-1228. CrossRef Medline

Lee JM, Zipfel GJ, Choi DW (1999) The changing landscape of ischaemic brain injury mechanisms. Nature 399:A7-A14. CrossRef Medline

Lee JM, Grabb MC, Zipfel GJ, Choi DW (2000) Brain tissue responses to ischemia. J Clin Invest 106:723-731. CrossRef Medline

Liu QR, Lu L, Zhu XG, Gong JP, Shaham Y, Uhl GR (2006) Rodent BDNF genes, novel promoters, novel splice variants, and regulation by cocaine. Brain Res 1067:1-12. CrossRef Medline

Longo FM, Massa SM (2013) Small-molecule modulation of neurotrophin receptors: a strategy for the treatment of neurological disease. Nat Rev Drug Discov 12:507-525. CrossRef Medline

Lu B, Nagappan G, Guan X, Nathan PJ, Wren P (2013) BDNF-based synaptic repair as a disease-modifying strategy for neurodegenerative diseases. Nat Rev Neurosci 14:401-416. CrossRef Medline

Lyons MR, West AE (2011) Mechanisms of specificity in neuronal activity- regulated gene transcription. Prog Neurobiol 94:259-295. CrossRef Medline

McAllister AK, Katz LC, Lo DC (1997) Opposing roles for endogenous BDNF and NT-3 in regulating cortical dendritic growth. Neuron 18:767778. CrossRef Medline

McDowell KA, Hutchinson AN, Wong-Goodrich SJ, Presby MM, Su D, Rodriguiz RM, Law KC, Williams CL, Wetsel WC, West AE (2010) Reduced cortical BDNF expression and aberrant memory in Carf knock-out mice. J Neurosci 30:7453-7465. CrossRef Medline

Nagahara AH, Tuszynski MH (2011) Potential therapeutic uses of BDNF in neurological and psychiatric disorders. Nat Rev Drug Discov 10:209-219. CrossRef Medline

National Stroke Association (2010) Stroke 101. Available at http://www. stroke.org/site/DocServer/STROKE101_2010.pdf?docID = 4541.

Newman RA, Yang P, Pawlus AD, Block KI (2008) Cardiac glycosides as novel cancer therapeutic agents. Mol Interv 8:36-49. CrossRef Medline

Obianyo O, Ye K (2013) Novel small molecule activators of the Trk family of receptor tyrosine kinases. Biochim Biophys Acta 1834:2213-2218. CrossRef Medline

Prassas I, Diamandis EP (2008) Novel therapeutic applications of cardiac glycosides. Nat Rev Drug Discov 7:926-935. CrossRef Medline

Pruunsild P, Kazantseva A, Aid T, Palm K, Timmusk T (2007) Dissecting the human BDNF locus: bidirectional transcription, complex splicing, and multiple promoters. Genomics 90:397-406. CrossRef Medline

Rothman SM, Mattson MP (2013) Activity-dependent, stress-responsive BDNF signaling and the quest for optimal brain health and resilience throughout the lifespan. Neuroscience 239:228-240. CrossRef Medline

Schäbitz WR, Steigleder T, Cooper-Kuhn CM, Schwab S, Sommer C, Schneider A, Kuhn HG (2007) Intravenous brain-derived neurotrophic factor enhances poststroke sensorimotor recovery and stimulates neurogenesis. Stroke 38:2165-2172. CrossRef Medline

Suwanwela N, Koroshetz WJ (2007) Acute ischemic stroke: overview of recent therapeutic developments. Annu Rev Med 58:89-106. CrossRef Medline

Tapley P, Lamballe F, Barbacid M (1992) K252a is a selective inhibitor of the tyrosine protein kinase activity of the trk family of oncogenes and neurotrophin receptors. Oncogene 7:371-381. Medline

Thoenen H, Sendtner M (2002) Neurotrophins: from enthusiastic expectations through sobering experiences to rational therapeutic approaches. Nat Neurosci 5:1046-1050. CrossRef Medline

Wang JK, Portbury S, Thomas MB, Barney S, Ricca DJ, Morris DL, Warner DS, Lo DC (2006) Cardiac glycosides provide neuroprotection against ischemic stroke: discovery by a brain slice-based compound screening platform. Proc Natl Acad Sci U S A 103:10461-10466. CrossRef Medline

Withering W (1785) An Account of the floxglove and some of its medical uses with practical remarks on dropsy and other diseases. London: J and J Robinson.

Xie Z, Cai T (2003) Na+-K+-ATPase-mediated signal transduction: from protein interaction to cellular function. Mol Interv 3:157-168. CrossRef Medline

Yacoubian TA, Lo DC (2000) Truncated and full-length TrkB receptors regulate distinct modes of dendritic growth. Nat Neurosci 3:342-349. CrossRef Medline

Yang P, Menter DG, Cartwright C, Chan D, Dixon S, Suraokar M, Mendoza G, Llansa N, Newman RA (2009) Oleandrin-mediated inhibition of human tumor cell proliferation: importance of $\mathrm{Na}$, K-ATPase alpha subunits as drug targets. Mol Cancer Ther 8:2319-2328. CrossRef Medline

Zaleska MM, Mercado ML, Chavez J, Feuerstein GZ, Pangalos MN, Wood A (2009) The development of stroke therapeutics: promising mechanisms and translational challenges. Neuropharmacology 56:329-341. CrossRef Medline

Zhao KC, Zhu XY, Yi MG, Liu ZM, Song ZY (1986) Studies on the pharmacokinetics of ${ }^{3} \mathrm{H}$-neriifolin in rats. Yao Xue Xue Bao 21:572-579. Medline 